\title{
COLLECTION OF SAMPLES FOR A RECONNAISSANCE GEOCHEMICAL SURVEY FROM THE PEARY LAND - KRONPRINS CHRISTIAN LAND REGION, NORTH GREENLAND
}

\author{
Niels Henriksen
}

The regional geochemical reconnaissance survey carried out in 1978 and 1979 (Ghisler et al., 1979; Henriksen, 1980) was continued in 1980 with collection of stream sediments. The purpose was to provide information for an evaluation of the mineral potential and to obtain general geochemical data. As a new aspect of this activity, moss and soil samples were collected this year with the aim of evaluating plant material as a meaningful sampling media for future investigations of similar type. A special report on the investigations of the plant material is given by P. Mølgaard and E. Håkansson (this report).

A total of 328 samples were collected in 1980. These comprise 157 silt samples, 121 sand samples, 45 moss samples and 5 soil samples. Approximately $2 / 3$ of the samples represent regionally scattered samples from areas which have not been previously sampled. These areas include parts of the fold belt region in the north, Kronprins Christian Land in the east and parts of the platform area in the central region. The remaining $c .1 / 3$ of the samples represent special, more detailed collections from areas which, from the earlier investigations, were known to contain geochemical anomalies. The purpose of these more detailed collections was to see if the anomalies reflected by the occasional samples could be confirmed by a more detailed survey in specific areas. Most field parties contributed to the regional sampling and one team (N. Henriksen) carried out the special, more detailed collecting.

As in the previous years the sampling was undertaken in relation to the local drainage system, and in general streams of medium to small size were chosen. Two types of stream sediments were collected - sand and silt. The silt samples were approximately $200 \mathrm{~g}$ and the sand samples 1 litre in size.

In relation to the sampling the following information was noted for each locality: type of sample, stratigraphical level, lithology of bedrock in catchment area, stream width, colour of stream sediment and UTM coordinates.

The planned laboratory investigations will follow the same lines as those of the 1978 and 1979 samples (Ghisler \& Stendal, 1980; Steenfelt, 1980). Silt samples will be analysed using delayed neutron counting, excited X-ray fluorescence (EDX) and atomic absorption. A. Steenfelt will coordinate the laboratory investigations of the silt samples. The sand samples will be investigated by M. Ghisler and $\mathrm{H}$. Stendal, who will make heavy mineral concentrates and investigate the material in polished sections, and use geochemical methods (Atomic Absorption Spectrophotometry). The moss samples are dealt with by P. Mølgaard (Mølgaard \& Håkansson, this report).

The stratigraphical and regional distribution of this year's sampling is shown on fig. 26 . With this third year's sampling the total number of samples collected during the three seasons is 
STRATIGRAPHICAL UNIT

Main lithology

Platform - foreland area Peary Land-Kronprins Christian Land

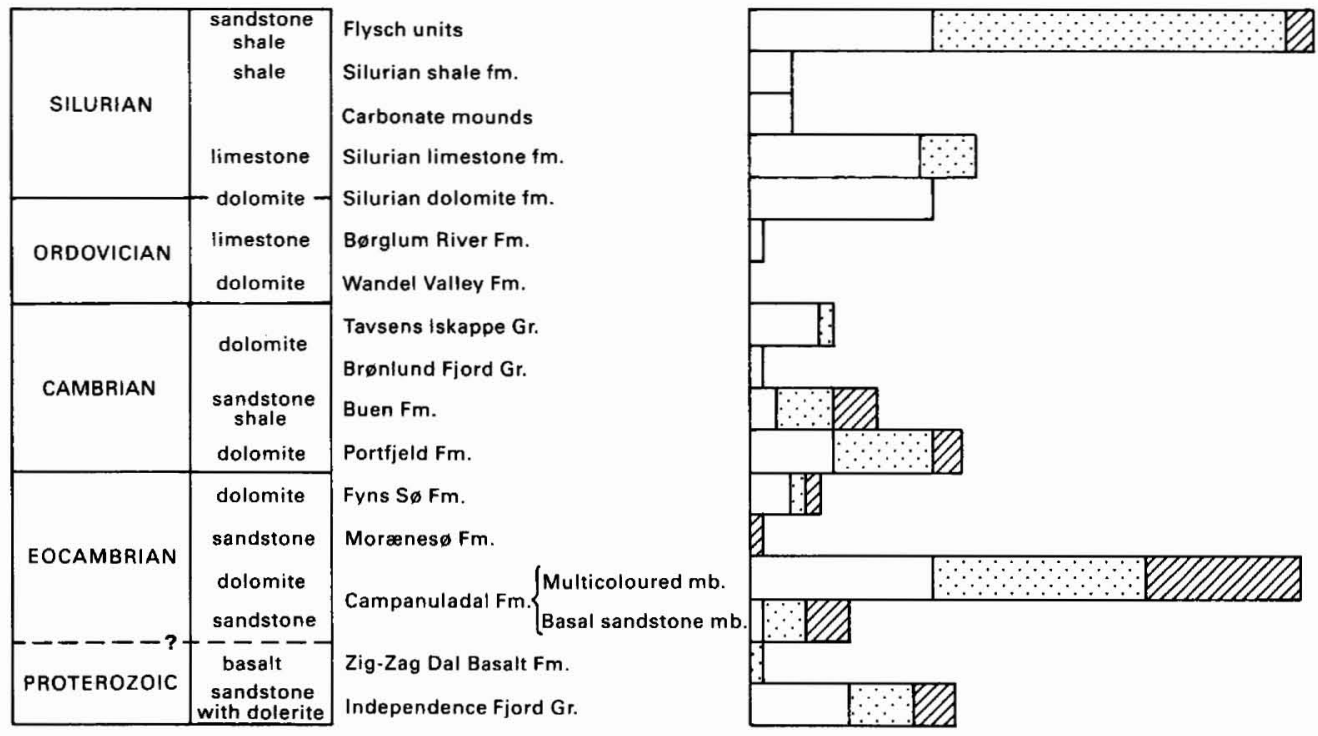

Fold belt in Kronprins Christian Land

\begin{tabular}{|c|c|c|}
\hline PROTEROZOIC & sandstone & Rivieradal sandstone \\
\hline PRECAMBRIAN & gneiss & Precambrian gneiss \\
\hline
\end{tabular}

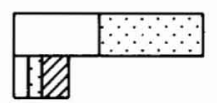

North Greenland fold belt - Johannes V. Jensen Land

\begin{tabular}{|c|c|c|}
\hline ORDOVICIAN & $\begin{array}{c}\text { sandstone } \\
\text { shale }\end{array}$ & Sydgletscher Gr. \\
\hline \multirow{3}{*}{ CAMBRIAN } & mudstone & Frigg Fjord Fm. \\
\hline & $\begin{array}{c}\text { sandstone } \\
\text { shale }\end{array}$ & Polkorridoren Gr. \\
\hline & limestone & Paradistjeld Gr. \\
\hline ? PROTEROZOIC & quartzite & Un-named quartzite group \\
\hline
\end{tabular}

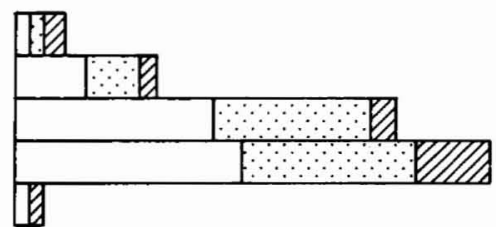

Wandel Sea Basin mainly Kronprins Christian Land area

Carboniferous to Tertiary mainly sandstone and shale

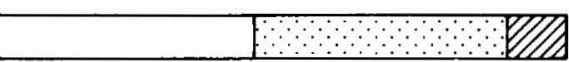

Kap Washington Group and intrusive centres. Johannes V. Jensen Land

Volcanic rocks at Kap Washington

Intrusive centres at Frigg Fjord

No. of samples

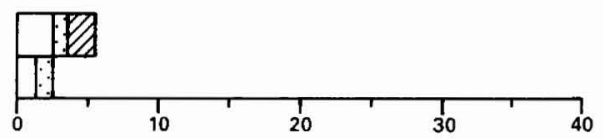

Silt samples $\quad \therefore \because$ Sand samples

Moss \& soil samples

Fig. 26. Stratigraphic distribution of stream sediments, and moss and soil samples for a reconnaissance geochemical survey of eastern North Greenland. 


\begin{tabular}{llr} 
& sand samples & 427 \\
$1978-1980$ & silt samples & 656 \\
& moss samples & 64 \\
\cline { 2 - 2 } & &
\end{tabular}

The total area represented by the geochemical survey is $c .50000 \mathrm{~km}^{2}$ and the sample density in the reconnaissance survey corresponds therefore to approximately 1-2 samples per $20 \mathrm{~km}^{2}$, although with a rather heterogeneous scatter.

\section{References}

Ghisler, M., Henriksen, N., Steenfelt, A. \& Stendal, H. 1979: A reconnaissance geochemical survey in the Proterozoic-Phanerozoic platform succession of the Peary Land region, North Greenland. Rapp. Grønlands geol. Unders. 88, 85-91.

Ghisler, M. \& Stendal H. 1980: Geochemical and ore microscopic investigations on drainage sands from the Peary Land region, North Greenland. Rapp. Gronlands geol. Unders. 99, 121-128.

Henriksen, N. 1980: Collection of stream sediments for a reconnaissance geochemical survey from the Peary Land region, North Greenland. Rapp. Grønlands geol. Unders. 99, 119-120.

Steenfelt, A. 1980: The geochemistry of stream silt, North Greenland. Rapp. Grønlands geol. Unders. 99, 129-135. 